fournal of Medical Genetics (1976). 13, 142-147.

\title{
Haemoglobin M Hyde Park occurring as a fresh mutation: diagnostic, structural, and genetic considerations*
}

\author{
GEORGE STAMATOYANNOPOULOS, PETER E. NUTE, ELOISE GIBLETT, \\ JAMES DETTER, and RONALD CHARD
}

From Departments of Medicine (Division of Medical Genetics), Anthropology and Laboratory Medicine, University of Washington, Seattle, Washington; the Hematology Division, Children's Orthopedic Hospital, Seattle, Washington; and the Immunogenetics Laboratory, King County Blood Bank, Seattle, Washington, USA.

Summary. Hb M Hyde Park disease was detected in a girl who for several years was thought to have cyanotic heart disease. The problems of recognizing the condition are outlined and clues to diagnosis are discussed. Evidence for heme loss from the aberrant $\beta$ chains of $\mathrm{Hb} \mathrm{M}$ Hyde Park and production of an unstable molecule is presented. The normal haematological findings in the patient's parents, as well as their blood groups and isozymes, suggest that the occurrence of her $\mathrm{Hb} \mathrm{M}$ Hyde Park was the result of a fresh mutation.

Cyanosis can be produced by three types of structurally defective haemoglobins: abnormal methaemoglobins (haemoglobins $M$ ), unstable haemoglobins, or haemoglobins with greatly reduced affinities for oxygen.

In haemoglobin $\mathbf{M}$ disease, cyanosis is the result of an accumulation in the red cell of a methaemoglobin having aberrant spectral and ligand-binding properties; the molecular basis of the defect appears to be a stabilization of heme iron in the ferric state by the formation of ionic links between the iron atom and the abnormal amino acid residue (Gerald and Efron 1961; Perutz and Lehmann 1968; Greer 1971). In unstable haemoglobin disease there is increased methaemoglobin formation caused primarily by disturbances in the tertiary structure of the heme pocket. Though the tendency for oxidation is a common characteristic of unstable haemoglobins, methaemoglobin accumulation to levels necessary to produce clinically recognizable cyanosis is relatively rare in unstable haemoglobin disease. The third type of haemoglobinopathic cyanosis is exemplified by $\mathrm{Hb}$ Kansas disease (Reissman, Ruth, and Nomura, 1961; Bonaventura

\footnotetext{
Received 1 April 1975.

* Supported by Grant GM-15253 from the National Institutes of
} Health. and Riggs, 1968); the abnormal allosteric properties of this molecule and its strikingly decreased oxygen affinity prohibit adequate oxygenation of blood in the lungs; cyanosis is thus a product of abnormally high levels of deoxyhaemoglobin in circulating red cells.

Although it is rare, haemoglobinopathy must be considered as the underlying cause of cyanosis when the search for more common causes has been unproductive. Occasionally, however, there are diagnostic problems because of uncertainties about phenotypic manifestations, the absence of autosomal dominant transmission or misinterpretations of laboratory tests. These problems are illustrated by the sequence of events which finally led to the delineation of the cause of cyanosis in the proband of the present report.

\section{Case report}

The proband (Fig. 1) is a Caucasian female of Norwegian and German ancestry who was the product of a full-term, normal delivery. Her medical history was unremarkable until the age of 3 months when, upon routine examination, a heart murmur was detected. Cyanosis was observed one month later, and at 5 months of age she was admitted to a paediatric hospital because of deep cyanosis following a crying spell. Physical examination revealed a grade $2 / 6$ systolic murmur heard 
TABLE I

HAEMATOLOGICAL FINDINGS OF PROBAND AND HER PARENTS

\begin{tabular}{|c|c|c|c|c|c|c|c|c|}
\hline Subject & Date & $\underset{(\mathrm{g} / \mathrm{dl})}{\mathrm{Hb}}$ & $\underset{\left(10^{6} / \mathrm{mm}^{3}\right)}{\mathrm{RBC}}$ & $\begin{array}{l}\text { Hct } \\
(\%)\end{array}$ & $\underset{(\mathrm{pg})}{\mathrm{MCH}}$ & $\underset{\left(\mu^{3}\right)}{\operatorname{MCV}}$ & $\underset{(\%)}{\mathrm{MCHC}}$ & $\underset{(\%)}{\text { Reticulocytes }}$ \\
\hline $\begin{array}{l}\text { Proband } \\
\text { Mother } \\
\text { Father }\end{array}$ & $\begin{array}{l}\text { April } 1972 \\
\text { April } 1972 \\
\text { April } 1972\end{array}$ & $\begin{array}{l}12.5 \\
13.2 \\
14.5\end{array}$ & $\begin{array}{l}4.54 \\
4.47 \\
4.58\end{array}$ & $\begin{array}{l}39.5 \\
38 \\
44\end{array}$ & $\begin{array}{l}27.6 \\
29 \\
32\end{array}$ & $\begin{array}{l}87 \\
85 \\
96\end{array}$ & $\begin{array}{l}31.6 \\
34 \\
33\end{array}$ & $\begin{array}{l}5.8 \\
0.7 \\
0.6\end{array}$ \\
\hline
\end{tabular}

best along the left sternal border. There was no hepatomegaly or other evidence of congestive heart failure. The electrocardiogram showed right axis deviation and a chest $x$-ray revealed decreased pulmonary vascular markings. The clinical impression at discharge was probable pulmonary stenosis with an intracardiac rightto-left shunt at either the atrial or ventricular level.
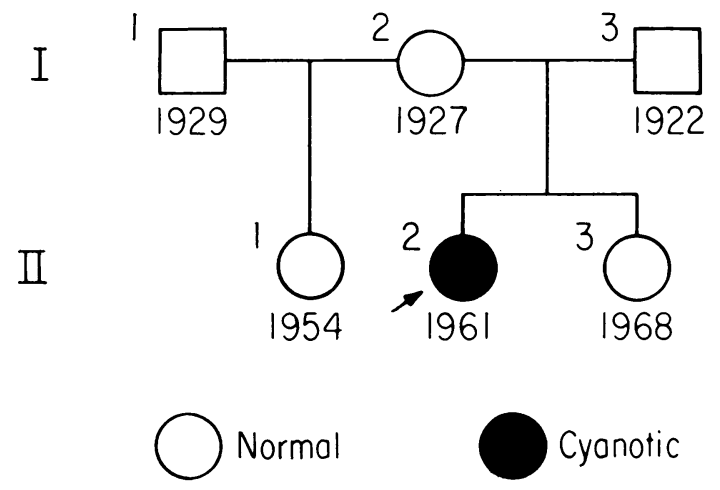

FIG. 1. Pedigree of the proband.

After this period in hospital, the proband underwent several additional clinical evaluations. Her exercise was restricted and frequent rest advised on the presumption that she suffered from congenital heart disease. She was permitted to attend school half days, but was not allowed to participate in peer group exertional activities. Her parents enforced rest periods and, ultimately, she was sleeping about 15 hours daily. During this period, she continued to grow and develop normally and required no admittance to hospital.

At age 10 she was admitted to Children's Orthopedic Hospital (Seattle) for cardiac evaluation. Catheterization of the right side of the heart revealed normal atrial, ventricular, pulmonary artery, and wedge pressures. Oxygen saturation levels in the right heart and brachial artery were low ( $43 \%$ and $56 \%$, respectively), but the angiograms were normal and there was no evidence of shunting at any level. At this point, congenital methaemoglobinaemia was suspected, but dismissed when the methaemoglobin level (determined according to Evelyn and Malloy, 1938) was reported to be $1.8 \%$ $(0.23 \mathrm{~g} / 100 \mathrm{ml}$ of whole blood). At this time the raised reticulocyte count was observed, so the patient's haematological status was further evaluated. Electrophoresis of haemoglobin revealed a poorly defined minor fraction of slightly greater mobility than $\mathrm{Hb} \mathrm{A}_{2}$; this fraction, together with $\mathrm{Hb} \mathrm{A}_{2}$, appeared to constitute about $7 \%$ of the total haemoglobin. The presence of an abnormal haemoglobin as well as a high reticulocyte count suggested the presence of an unstable haemoglobin.

Neither parent of the proband gave a history of cyanosis, and both were found to be haematologically normal (Table I); no other cases of cyanosis were known in the family (Fig. 1). When the proband was conceived, her father was 39 years old, and her mother was 34 .

\section{Materials and Methods}

Routine haematological studies were performed using standard techniques. Haemoglobin stability was assessed by testing for thermolability (Schneiderman, Junga, and Fawley, 1970; Carrell and Kay, 1972) and for induced Heinz body formation (Papayannopoulou and Stamatoyannopoulos, 1974). Electrophoresis of haemoglobin was performed in starch gels using a Tris-borate-

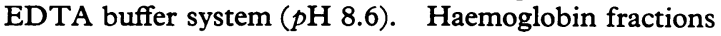
were isolated by chromatography in DEAE-Sephadex columns using $0.05 \mathrm{M}$ Tris-HCl buffers, applying a gradient ranging from $p \mathrm{H} 8.2$ to $p \mathrm{H}$ 7.3. Hybridization experiments were carried out as described by Huehns, Shooter, and Beaven (1962). Globin was prepared by the acidified acetone method (Rossi-Fanelli, Antonini, and Caputo, 1958), and globin chains were isolated on a column of carboxymethyl cellulose (Whatman CM-52) according to Clegg, Naughton, and Weatherall (1968). The isolated chains were dialysed, lyophilized, aminoethylated (Jones, 1964), and trypsin-digested (trypsinTPCK, Worthington). The tryptic digests $(2 \mathrm{mg}$ ) were subjected to paper electrophoresis in a buffer of pyridine,

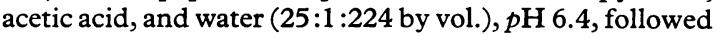
by descending chromatography in a solvent of pyridine, isoamyl alcohol, and water (7:7:6 by vol.), according to Baglioni (1965). Peptides were stained with buffered $0.2 \%$ ninhydrin in acetone as described by Easley (1965). For preparative purposes, peptide maps were made using $6.5 \mathrm{mg}$ trypsin-digested aminoethylated chains. After location of peptides by staining with unbuffered $0.02 \%$ ninhydrin in acetone, selected peptides were eluted (Sanger and Tuppy, 1951), hydrolysed in $6 \mathrm{~N} \mathrm{HCl}$ in sealed capillary tubes for 24 hours at $108^{\circ} \mathrm{C}$, and analysed on a Beckman 120B amino analyser.

Red cell isozymes from the proband and her parents were examined as described by Giblett (1969) and Brewer (1970), and levels of red cell 2, 3-diphosphoglyceric acid (2, 3-DPG) were measured according to Detter et al (1975). Measurement of oxygen dissociation was accomplished by the mixing technique of Lenfant et al (1969). 


\section{Results}

Haematological Findings. Haematological data from the proband and her parents appear in Table I. Reticulocyte counts in the proband were raised $(5.8 \%)$ and haptoglobin was absent. With the stability test of Carrell and Kay (1972) the patient's haemolysate produced a fine precipitate. Her red cells had no preformed Heinz bodies, but after incubation for 24 to 48 hours at $37^{\circ} \mathrm{C}$, induced Heinz bodies were observed. The whole blood showed a normal oxygen affinity $\left(\mathbf{P}_{50}\right.$ for proband $=27.8 \mathrm{~mm} \mathrm{Hg}$; normal $=27-28 \mathrm{~mm} \mathrm{Hg}$ ), and levels of erythrocytic 2, 3-DPG were normal $(14.5 \mu \mathrm{mol}$ /g Hb).

Electrophoretic and chromatographic studies. The haemoglobin electrophoretic patterns of both parents were normal; however, as indicated above, the patient's pattern contained a band of haemoglobin migrating ahead of $\mathrm{Hb} \mathrm{A}_{2}$, while the $\mathrm{Hb} \mathrm{A}_{2}$ band itself appeared broadened anodally. After heating, the abnormal haemoglobin band disappeared (Fig. 2) suggesting molecular instability.

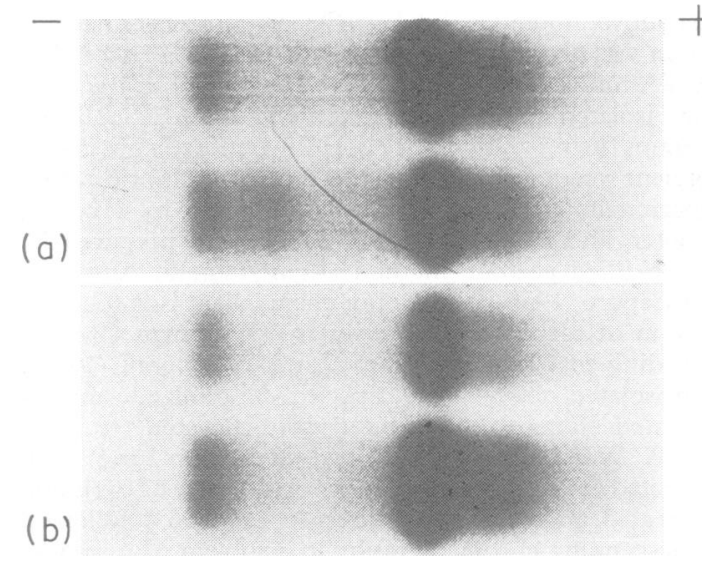

FIG. 2. Starch-gel electrophoresis of the proband's haemolysate and haemolysate of her father. Samples treated for 2 minutes at (a) $65^{\circ} \mathrm{C}$, and (b) $70^{\circ} \mathrm{C}$.

Column chromatography of the proband's haemoglobins produced three peaks; some material remained bound to the top of the column. On starch-gel electrophoresis the first peak had the mobility of $\mathrm{Hb} \mathrm{A}_{2}$ while the third was indistinguishable from $\mathrm{Hb} \mathrm{A}$; the second, abnormal peak produced two electrophoretic bands: one migrated slightly faster than $\mathrm{Hb} \mathrm{A}_{2}$, thus accounting for the increased breadth of the $\mathrm{Hb} \mathrm{A}_{2}$ band in the whole haemolysate. The more rapidly moving abnormal band corresponded to the component in the haemolysate moving faster than $\mathrm{Hb} \mathrm{A}_{2}$.

On spectrophotometry, the abnormal chromatographic fraction had an $\mathrm{OD}_{280} / \mathrm{OD}_{540}$ ratio of 3.24, whereas ratios of 2.37, 2.38, and 2.39 were obtained with similar concentrations of $\mathrm{Hb} \mathrm{A}$ from the proband's parents and an unrelated normal control. These results indicated that there were fewer heme groups per polypeptide chain in the eluate containing the abnormal chromatographic peak. This finding recalled the fact that electrophoretic and chromatographic fractions containing haemoglobin tetramers lacking one or two heme groups have been observed in cases of electrophoretically 'silent' unstable haemoglobins (Jacob and Winterhalter, 1970).

Hybridization studies. Canine haemoglobin and an eluate from the abnormal chromatographic peak were mixed, dissociated, and allowed to recombine. The $\alpha_{2}{ }^{\mathrm{A}} \beta_{2}{ }^{\text {canine }}$ tetramer was readily formed and occupied the expected electrophoretic position

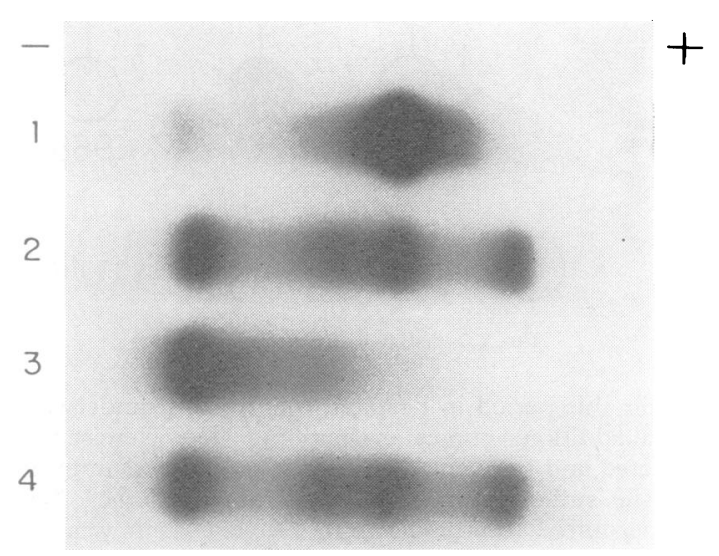

FIG. 3. Hybridization of the abnormal fractions with canine haemoglobin. 1: normal control; 2 and 4 : hybridization of $\mathrm{Hb} \mathrm{A}$ with canine haemoglobin; 3: hybridization pattern of $\mathrm{Hb}$ canine and the chromatographically purified abnormal haemoglobin. Note the absence of haemoglobin $\alpha_{2}$ canine $\beta_{2}{ }^{x}$.

(Fig. 3). However, a tetramer containing two canine $\alpha$ chains and two human $\beta$ chains was not detected in starch gels, indicating that the abnormal haemoglobin contained an unstable $\beta$ chain

Structural analysis. On maps of the tryptic peptides of aminoethylated $\beta$ chains isolated from the abnormal chromatographic fraction, peptide $\beta \mathrm{T}_{10}$ was shifted from its normal position to the area between peptides $\beta \mathrm{T}_{8-9}$ and $\beta \mathrm{T}_{11}$ (Fig. 4). Amino acid analysis of this peptide (Table II) yielded a composition identical to that of normal $\beta \mathrm{T}_{10}$, except for replacement of a histidyl residue by a tyrosyl 


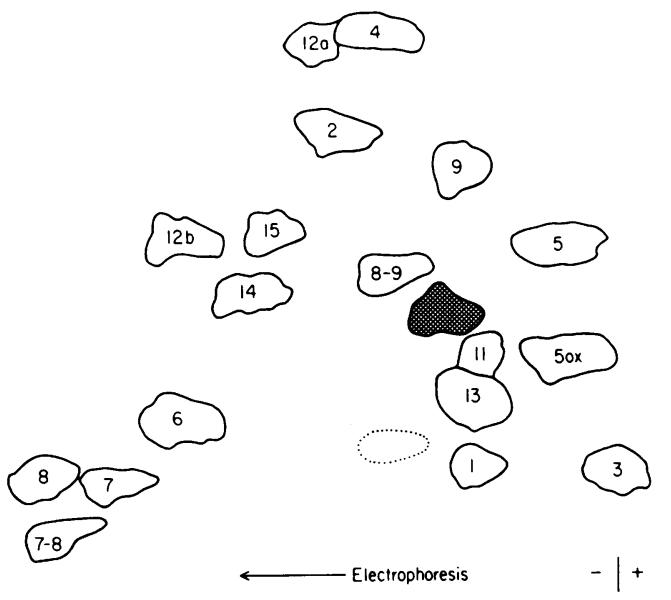

FIG. 4. Peptide map of the $\beta$ chain from the abnormal chromatographic fraction showing atypical position of peptide $\beta T_{10}$.

TABLE II

AMINO ACID COMPOSITION OF PEPTIDE $\beta \mathrm{T}_{10}$ FROM ABNORMAL CHAIN OF PROBAND

\begin{tabular}{l|c|c}
\hline \multicolumn{1}{c|}{ Amino acid } & Observed & Normal $\beta T_{10}$ \\
\hline Aspartic acid & 1.00 & 1 \\
Threonine & 1.75 & 2 \\
Serine & 0.95 & 1 \\
Glutamic acid & 1.05 & 1 \\
Glycine & 1.01 & 1 \\
Alanine & 1.02 & 2 \\
Leucine & 1.86 & 0 \\
Tyrosine & 0.77 & 1 \\
Phenylalanine & 0.95 & 1 \\
Lysine & 1.00 & 1 \\
AE-cysteine & 0.90 & 1 \\
Histidine & 0.00 & \\
\hline
\end{tabular}

Italics indicate residues involved

residue. The results indicated that the $\beta$ chains of the patient's abnormal haemoglobin differ from $\beta^{\mathrm{A}}$ chains by the substitution of tyrosine for histidine at position 92, an abnormality identical to that of $\mathrm{Hb}$ M Hyde Park (Heller, Coleman, and Yakulis, 1966).

Blood groups and red cell enzymes. Since both of the patient's parents were clinically normal and showed no traces of an electrophoretically abnormal haemoglobin, it seemed likely that the $\mathrm{Hb}$ $M$ Hyde Park in their daughter arose through a new mutation in a parental gamete. The alternative possibility of nonpaternity was not supported by analysis of isozyme and blood group markers (Tables III and IV).

TABLE III

RED CELL ISOZYME PHENOTYPES IN THE PROBAND AND HER PARENTS

\begin{tabular}{l|c|c|c}
\hline \multicolumn{1}{c|}{ Enzymes } & \multicolumn{3}{|c}{ Phenotypes } \\
\cline { 2 - 4 } & Father & Mother & Proband \\
\hline Acid phosphatase & BC & BA & AC \\
Adenosine deaminase & 1 & 1 & 1 \\
6-Phosphogluconate & A & A hydrogenase & A \\
Glucose-6-phosphate & B & BA & B \\
dehydrogenase & 1 & 1 & 1 \\
Peptidase A & 1 & 1 & 1 \\
Peptidase B & 1 & 1 & 1 \\
Peptidase C & $2-1$ & $2-1$ & $2-1$ \\
Phosphoglucomutase 1 & 1 & 1 & 1 \\
Phosphoglucomutase 2 & 1 & 1 & 1 \\
Adenylate kinase & 1 & 1 & 1 \\
Isocitrate dehydrogenase & 1 & 1 & 1 \\
Enolase & 1 & 1 & 1 \\
2,3-diphosphoglycerate mutase & 1 & 1 & 1 \\
Phosphoglycerate mutase & 1 & 1 & 1 \\
Phosphohexose isomerase & 1 & 1 & 1 \\
Phosphoglycerate kinase & 1 & $2-1$ & $2-1$ \\
Glutamic oxaloacetic transaminase & $2-1$ & 1 & 1 \\
Glutamic pyruvate transaminase & 1 & 1 & 1 \\
Phosphofructokinase & 1 & 1 & 1 \\
Aldokinase & 1 & 1 & 1 \\
Glyceraldehyde-3-phosphate & 1 & 1 & 1 \\
dehydrogenase & 1 & 1 & \\
Pyruvate kinase & &
\end{tabular}

\section{Discussion}

The investigation of this family illustrates some of the diagnostic, genetic, and biochemical problems inherent in the study of haemoglobin variants which cause cyanosis.

During infancy, the proband had cyanosis, a systolic murmur, and decreased pulmonary vascular markings, all suggesting congenital heart disease. This diagnosis was finally disproven when cardiac catheterization and angiography failed to reveal the postulated pulmonary stenosis and right-to-left shunt. One sign suggestive of a $\beta$-chain abnormality as a cause of cyanosis, i.e. the initial appearance of cyanosis around the third month of life (when much of the fetal $\gamma$ globin has been replaced by the adult $\beta$ globin) was not evaluated in this case. The

TABLE IV

BLOOD GROUPS IN PROBAND AND PARENTS

\begin{tabular}{|c|c|c|c|c|c|c|c|c|c|c|c|c|c|c|c|c|c|}
\hline \multirow{2}{*}{ Individual } & \multicolumn{2}{|c|}{$\mathrm{ABO}$} & \multicolumn{4}{|c|}{$\mathbf{R h}$} & \multicolumn{4}{|c|}{ Kell } & \multicolumn{2}{|c|}{ Duffy } & \multirow{2}{*}{$\begin{array}{l}\mathbf{P} \\
P_{1}\end{array}$} & \multicolumn{4}{|c|}{ MNSs } \\
\hline & $\mathbf{A}$ & B & C & $\mathrm{D}$ & $\mathbf{E}$ & c & $\mathbf{K}$ & $\mathbf{k}$ & $\mathrm{Kp}^{\mathrm{a}}$ & $\mathrm{Kp}^{\mathrm{b}}$ & $F^{a}{ }^{a}$ & $F^{b}$ & & $\mathbf{M}$ & $\mathbf{N}$ & $\mathrm{s}$ & $\mathbf{s}$ \\
\hline $\begin{array}{l}\text { Father } \\
\text { Mother } \\
\text { Proband }\end{array}$ & $\begin{array}{l}\frac{A_{2}}{A} \\
\overline{A_{2}}\end{array}$ & $\begin{array}{l}- \\
\overline{-}\end{array}$ & $\begin{array}{l}+ \\
+ \\
+\end{array}$ & $\begin{array}{l}+ \\
+ \\
+\end{array}$ & $\bar{z}$ & $\begin{array}{l}- \\
-\end{array}$ & $\begin{array}{l}- \\
-\end{array}$ & $\begin{array}{l}+ \\
+ \\
+\end{array}$ & $\bar{z}$ & $\begin{array}{l}+ \\
+ \\
+\end{array}$ & \pm & $\begin{array}{l}+ \\
+ \\
+\end{array}$ & $\begin{array}{l}+ \\
+ \\
+\end{array}$ & $\begin{array}{l}+ \\
+ \\
+\end{array}$ & $\frac{+}{+}$ & $\begin{array}{l}\bar{t} \\
+\end{array}$ & $\frac{+}{+}$ \\
\hline
\end{tabular}


possibility of $\mathrm{Hb} \mathrm{M}$ disease was raised when other causes of cyanosis were examined, but it was excluded when apparently normal levels of methaemoglobin were found in the patient's blood. This diagnostic error occurs when the clinician overlooks the fact that abnormal spectra and cyanide reactivity of structurally abnormal methaemoglobin invalidate measurements of total methaemoglobin made according to the procedure of Evelyn and Malloy. Thus, the inaccurately measured level of methaemoglobin in the proband led to fallacious exclusion of methaemoglobinaemia, even though approximately $40 \%$ of her $\beta$ chains contained ferric heme. The subsequent discovery of reticulocytosis and of electrophoretically abnormal haemoglobin components suggested the possibility of unstable haemoglobin disease. However, this interpretation could not account for the cyanosis unless the abnormal electrophoretic components were produced by loss of heme groups from an electrophoretically 'silent' abnormal ferrihaemoglobin, i.e. a haemoglobin $\mathbf{M}$. Structural studies confirmed this interpretation, showing the patient to be heterozygous for $\mathrm{Hb} \mathrm{M}$ Hyde Park.

Haemoglobin M Hyde Park has several interesting properties that have been examined in detail by Hayashi et al (1968) and Ranney et al (1968). $X$-ray crystallographic analysis is impeded by the loss of $\beta$-heme groups from 20 to $30 \%$ of the molecules in crystalline preparations (Greer, 1971), an observation compatible with the haematological manifestations of molecular instability. Thus, the presence of this variant haemoglobin has two types of functional consequences: methaemoglobinaemic cyanosis caused by the intact $\mathrm{Hb} \mathrm{M}$ Hyde Park tetramer, and haemolytic anaemia as a result of precipitation of globin after the loss of heme groups from the structurally aberrant $\beta$ chains.

The appearance of haemoglobin M Hyde Park in this patient is probably the result of a new mutation in one of her parents' gametes. Several other examples of functionally abnormal haemoglobins arising from new mutations have been described (see Bunn et al, 1972; Koler et al, 1973). The physician must be aware of this possibility and avoid excluding the diagnosis of haemoglobinopathic cyanosis when the expected autosomal dominant transmission of the defect is absent. All the known cases of $\mathrm{Hb} \mathrm{M}$ Hyde Park have resulted from fresh mutations, suggesting possible loss of fitness in individuals with this haemoglobin. Such a decrease in fitness could be explained on physiological grounds as a result of the mild haemolytic anemia and the presence of a haemoglobin fraction which does not participate in oxygen transport.

\section{REFERENCES}

Baglioni, C. (1965). Abnormal human hemoglobins. X. A study of hemoglobin Lepore Boston. Biochimica et Biophysica Acta, 97, 3746.

Bonaventura, J. and Riggs, A. (1968). Hemoglobin Kansas, a human hemoglobin with a neutral amino acid substitution and an abnormal oxygen equilibrium. Fournal of Biological Chemistry, 243, 980-991.

Brewer, G. J. (1970). An Introduction to Isozyme Techniques. Academic Press, New York and London.

Bunn, H. F., Bradley, T. B., Davis, W. E., Drysdale, J. W., Burke, J. F., Beck, W. S., and Laver, M. B. (1972). Structural and functional studies on hemoglobin Bethesda $\left(\alpha_{2} \beta_{2}{ }^{145} \mathrm{H1s}\right)$, a variant associated with compensatory erythrocytosis. Fournal of Clinical Investigation, 51, 2299-2309.

Carrell, R. W. and Kay, R. (1972). A simple method for the detection of unstable haemoglobins. British fournal of Haematology, 23, 615-619.

Clegg, J. B., Naughton, M. A., and Weatherall, D. J. (1968). Separation of the $\alpha$ and $\beta$-chains of human haemoglobin. Nature (London), 219, 69-70.

Detter, J. C., Gibson, D. F., MacMillan, S. F., and Oas, T. (1975). Manual determination of intraerythrocytic 2,3-diphosphoglycerate in whole blood by enzymatic analysis and comparison with ionexchange chromatography. Clinical Chemistry. 21, 376-380.

Easley, C. W. (1965). Combinations of specific color reactions useful in the peptide mapping technique. Biochimica et Biophysica Acta, 107, 386-388.

Evelyn, K. A. and Malloy, H. T. (1938). Microdetermination of oxyhemoglobin, methemoglobin, and sulfhemoglobin in a single sample of blood. Fournal of Biological Chemistry, 126, 655-667.

Gerald, P. S. and Efron, M. L. (1961). Chemical studies of several varieties of hemoglobin M. Proceedings of the National Academy of Sciences of the United States of America, 47, 1758-1767.

Giblett, E. R. (1969). Genetic Markers in Human Blood. Blackwell Scientific Publications, Oxford and Edinburgh.

Greer, J. (1971). Three-dimensional structure of abnormal human haemoglobins $M$ Hyde Park and M. Iwate. Fournal of Molecular Biology, 59, 107-126.

Hayashi, A., Suzuki, T., Shimizu, A., Imai, K., Morimoto, H., Miyaji, T., and Shibata, S. (1968). Some observations on the physicochemical properties of hemoglobin M Hyde Park. Archives of Biochemistry and Biophysics, 125, 895-901.

Heller, P., Coleman, R. D., and Yakulis, V. J. (1966). Structural studies of haemoglobin M Hyde Park. In Proceedings of the 11th Congress of the International Society of Blood Transfusion, Sydney, Part 4, pp. 1073-1084.

Huehns, E. R., Shooter, E. M., and Beaven, G. H. (1962). On the recombination of canine and human haemoglobins. Fournal of Molecular Biology, 4, 323-328.

Jacob, H. and Winterhalter, K. (1970). Unstable hemoglobins: the role of heme loss in Heinz body formation. Proceedings of the National Academy of Sciences of the United States of America, 65, 697-701.

Jones, R. T. (1964). Structural studies of aminoethylated hemoglobins by automatic peptide chromatography. Cold Spring Harbor Symposia on Quantitative Biology, 29, 297-308.

Koler, R. D., Jones, R. T., Bigley, R. H., Litt, M., Lovrien, E., Brooks, R., Lahey, M. E., and Fowler, R. (1973). Hemoglobin Casper: $\beta 106$ (G8) Leu $\rightarrow$ Pro. American fournal of Medicine, 55, 549-558.

Lenfant, C., Ways, P., Aucutt, C., and Cruz, J. (1969). Effect of chronic hypoxic hypoxia on the $\mathrm{O}_{2}-\mathrm{Hb}$ dissociation curve and respiratory gas transport in man. Respiration Physiology, 7, 7-29.

Papayannopoulou, Th. and Stamatoyannopoulos, G. (1974). Stains for inclusion bodies. In The Detection of Hemoglobinopathies, pp. 32-38. Ed. by R. M. Schmidt, T. H. J. Huisman, and H. Lehmann. CRC Press, Cleveland.

Perutz, M. F. and Lehmann, H. (1968). Molecular pathology of human haemoglobin. Nature (London), 218, 902-909.

Ranney, H. M., Nagel, R. L., Heller, P., and Udem, L. (1968). Oxygen equilibrium of hemoglobin $\mathbf{M}_{\text {Hyde Park. Biochimica et }}$ Biophysica Acta, 160, 112-115.

Reissman, K. R., Ruth, W. E., and Nomura, T. (1961). A human hemoglobin with lowered oxygen affinity and impaired hemeheme interactions. Fournal of Clinical Investigation, 40, 18261833. 
Rossi-Fanelli, A., Antonini, E., and Caputo, A. (1958). Studies on the structure of hemoglobin. I. Physicochemical properties of human globin. Biochimica et Biophysica Acta, 30, 608-615.

Sanger, F. and Tuppy, H. (1951). The amino-acid sequence in the phenylalanyl chain of insulin. I. The identification of lower peptides from partial hydrolysates. Biochemical fournal, 49, 463-481.

Schneiderman, L. J., Junga, I. G., and Fawley, D. E. (1970)

Effect of phosphate and non-phosphate buffers on thermolability of unstable haemoglobins. Nature (London), 225, 1041-1042. 